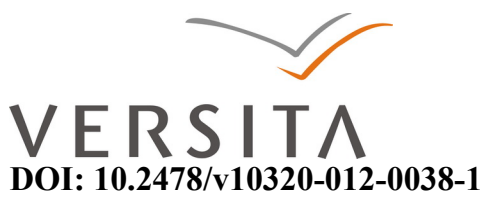

\title{
DIFFERENT HORRORS, SAME HELL: THE GENDERED NATURE OF HOLOCAUST SUFFERING
}

\author{
ROXANA GHIŢĂ \\ West University of Timişoara, \\ 4, Pârvan Blvd, Timișoara, Romania \\ roxana.elena.gh@gmail.com
}

\begin{abstract}
While most Holocaust memoirs and stories considered canonical present mostly the male viewpoint on loss and traumatic experiences, a shade is cast over women's representations of the horrors of the Shoah. Although the suffering and horror experienced by both men and women cannot be quantified, women were subject to different traumatic experiences, as they were objects of hatred not only for belonging to an "impure race", but also for being mothers and "sexual beings."
\end{abstract}

Key words: gender differences, gender stereotypes, Holocaust, trauma, memoirs, photography.

\section{Introduction}

In Holocaust studies, gender distinctions have largely been ignored, either because women have been perceived as marginal to the Holocaust, or because these distinctions have been seen as possible distractions from the central feature of the history of the Holocaust itself. The "canonical" corpus of Holocaust literature presents mostly the male viewpoint, and thus men's traumatic experiences and memories have become the "norm" for describing loss and suffering.

Holocaust scholars disagree over whether women and men should be considered two distinct entities in the study of the Nazi genocide. Writers such as Ruth Bondy and Lawrence Lager, for example, challenge the idea that women should be studied separately in historical and social analyses of mass extermination. Even though she is the author of an entire volume offering insight into women's experience at Theresienstadt, 
Bondy's introductory remark (1998:310) very clearly states her position regarding a gender-based approach to Holocaust studies:

Zyklon B [lethal gas] did not differentiate between men and women; the same death swept them all away. Because the same fate awaited all Jews, I approached the writing of this chapter with grave reservations: why should I focus on women? Any division of the Holocaust and its sufferers according to gender seemed offensive to me. This issue of gender seems to belong to another generation, another era.

Lawrence Langer (1998:362) also challenged the moral legitimacy of what he considered to represent the privileging of one group over another in Holocaust studies:

The pain of loss and the relief of survival remain entwined in the memory of those lucky enough to have outlived the atrocities. All efforts to find a rule of hierarchy in that darkness, whether based on gender or will, spirit or hope, reflect only our own need to plant a life sustaining seed in the barren soil that conceals the remnants of two-thirds of European Jewry. The sooner we abandon this design, the quicker we will learn to face such chaos with unshielded eyes.

In contrast to these points of view, scholars such as Carol Rittner, Dalia Ofer, Leonore Weitzman and Joan Ringelheim share the firm conviction that the study of women during the Holocaust is not only justifiable but necessary in order to redress the absence of women's lives and experiences in the documentation of Holocaust history and the preservation of Holocaust memory. After a long period of research in the field of Holocaust studies, Rittner and Roth (1993:XI) reached the conclusion that

Relatively little attention has been paid to women's experiences before, during or after the Holocaust. Much of the best witness literature by women, the autobiographical accounts of those who survived the Holocaust is out of print or not easily accessible. Much of the most widely read scholarship - historical, sociopolitical, philosophical and religious - treats the Holocaust as if sexual and gender differences did not make a difference [...] Thus the particularities of women's experiences and reflections have been submerged and ignored.

Joan Ringelheim (1998:350) asserts, on the one hand, the fact that the pain and the suffering experienced by both men and women during the Holocaust cannot be 
quantified and compared, but on the other hand she argues for the inclusion of womencentred perspectives that focus on "gender-specific" traumas such as the fact that

Jewish women carried the burden of sexual victimization, pregnancy, abortion, childbirth, killing of newborn babies in the camps to save mothers, care of children, and many decisions about separation from children. For Jewish women the Holocaust produced a set of experiences, responses, and memories that do not always parallel those of Jewish men.

\subsection{Sources of gender differences during the Holocaust}

In their article "Women and the Holocaust" (1998), Dalia Ofer and Leonore Weitzman identify four sources of gender differences during the Holocaust which legitimate the need for a gender-based approach to Holocaust studies:

\section{- Pre-war roles and responsibilities of men and women:}

Jewish men and women lived in a cultural and social environment that endowed them with "different spheres of knowledge, expertise, social networks and opportunities with which they faced the Nazi onslaught" (Ofer and Weitzman 1998).

\section{- Anticipatory reactions:}

Jews assumed that Nazis would not hurt their women and children, and only men were in any real danger. Therefore, Jewish women were those who devised strategies to help their men hide or migrate. They used to go to the police, the SS and the municipality to protest arbitrary actions against their families and to try to gain the release of their male relatives who had been detained. In the early days of the German invasion of Poland, Jewish women urged their men to escape to Russia, and, as a result, at a certain moment during the war they formed the majority of the Jewish population of both Warsaw and Lodz.

\section{- German policy and treatment of men and women:}

In the early years of the war Nazis issued different regulations for men and for women which provided specific constraints, on the one hand, and opportunities, on the other. One Nazi concentration camp, Ravensbrück, was created especially for women and children. 132,000 women were imprisoned there, from more than 20 countries, and about 92,000 died of starvation or illness, or were executed (http://jwa.org/encyclopedia). Women were prone to be subjected to acts of sexual harassment, rape or sexual slavery, 
despite the fact that Germans were prohibited from having any sexual relations with Jews because of Rassenschande (racial shame, behaviour beneath the dignity of one's race). Atrocious medical experiments were conducted on women's reproductive organs and on different ways of sterilising them. Moreover, there were particularly cruel experiments in which the doctors taped the breasts of breast-feeding mothers so that they would not be able to feed their newborn babies and then measured the endurance of the mothers and the babies. The mothers, in an agony of suffering, were forced to participate until their babies were starved to death.

In Theresienstadt, an order for compulsory abortion was issued in July 1943. After that date, any woman who gave birth to a child was sent, together with her baby and her husband, on the next "transport to the East" (to the Auschwitz death camp). This lager was, as Ruth Klüger (2001:70) names it, "the stable that supplied the slaughterhouse". In Auschwitz, any woman who was visibly pregnant, or who was holding a child, was sent to the gas chambers. If a woman was in the first months of pregnancy, it was possible for her not to be detected, and to be selected for slave labour.

Both men and women experienced all kinds of humiliation, especially as on arrival in the concentration camps their hair was shaved and their bodies exposed in front of strangers. However, women experienced this as sexual humiliation to a greater extent than men, as they were being gazed upon by Nazi soldiers. Furthermore, because of starvation and its effect on menstruation, women lived under the constant terror that they might never be able to conceive children again.

Forced prostitution was also a common phenomenon in the camps, as women were used not only as rewards for elite male prisoners, but also as a "safeguard" against homosexuality among German soldiers. They were also used in experiments conducted on gay male prisoners who were forced to have sexual relations with women.

\section{- $\quad$ Responses of Jewish men and women to Nazi persecution}

The victims of the Holocaust answered Nazi persecution by "drawing on genderspecific skills and resources". What seems to be specific to women during their camp imprisonment was the formation of camp-sister relationships, the Lagerschwestern. These close family-like ties that women formed were meant for mutual help and strength 
in a sea of terror. Apparently, no parallel term describing male friendship as "brotherly" exists for men during that period.

Moreover, throughout the Holocaust, women had to face a terrible decision that men did not, namely the mothers of young children had the choice of presenting themselves to be selected as workers, and abandoning their children, or staying with them and being sent together to the gas chambers. Only two of about six hundred mothers of young children presented themselves for the selection, as all the others decided to stay with their children until the end (http://jwa.org/encyclopedia). One such traumatic moment is illustrated in William Styron's novel Sophie's Choice, featuring a survivor of the Nazi concentration camps who was forced to choose between the lives of her two children when they were caught by the Nazis.

In order to preserve their faith, spiritual life and humanity, first and foremost, some women were able to continue observing their Jewish traditions. Thus they improvised prayers, lighted "candles" on the eve of holidays, fasted on Yom Kippur and abstained from eating bread at Passover, despite their permanent hunger. Furthermore, women sang, told stories and even gave theatrical performances in order to overcome the brutal realities of ghetto and camp life.

\subsection{Gender, trauma and narrativisation in Ruth Klüger's Still}

\section{Alive}

The importance of gender as an essential constituent of Jewish people's narrativisation of Holocaust is highly visible in survivors' memoirs. On the one hand, when we look at men's and women's accounts alongside each other, common elements that bridge the accounts may be noticed. Both men and women were, as Anna Reading (2002:74) states, "part of the same shattered and shattering gendered genocidal jigsaw". But on the other hand, these complex renderings of surviving the Holocaust are also articulated according to a gender-marked perspective, as the atrocities that men and women were subjected to were different to a certain extent, and they negotiated them and their personal survival differently.

Although the corpus of Holocaust literature by women is diverse and varied, several themes predominate. Some of these recurrent themes are gender specific, while 
others characterise Holocaust writing in general. Among the most striking images that occur in both men's and women's memoirs are the cattle freight cars, the hunger and the thirst, the Muselmänner, the name that Primo Levi gave to the walking dead in the camps, to men who wouldn't live long because they had reached the limits of pain and suffering, as well as the gradual dehumanisation of the prisoners that all the camp practices managed to bring about.

Ruth Klüger's volume of memoirs, Still Alive, features both these general topics and gender specific ones. As a child, Ruth saw her family's happy life in Vienna undermined and destroyed. She remembers the constant humiliation and terror she felt as a child:

\footnotetext{
'Oh, you are from Vienna'. Americans like to say. 'How lucky you are. What a charming city'. That's what they said even in the late forties, as if they had promptly forgotten what the war was about, and I'd reply incredulously, 'But I am Jewish'. They act as if that had nothing to do with the objective charm of waltzes and empresses with long hair and Mozart operas. And nowadays they think of The Sound of Music and of Schwarzenegger. But with the yellow Jewish star on one's coat, one didn't go on excursions or into museums. Even before we were required to wear it, half the city was forbidden, verboten, taboo, or out of reach for Jews. The signs telling Jews and dogs to stay outside were ubiquitous (2001:25).
}

When she was eleven, Ruth was deported with her mother to Theresienstadt, the first in a series of concentration camps which would become the setting for her shattered childhood. She vividly recollects the devastating hunger and thirst that she suffered from in the camps, not only because of their dreadful effects upon the body, but also because of the rapid deterioration of mental condition that these two triggered:

\footnotetext{
Those were my first weeks of protracted hunger [...] Hunger gnaws and weakens you. It takes up mental space which could otherwise be used for thinking. What can you do with your food ration to stretch it? (2001:75).

Hunger was less of a problem than thirst. [...] you only have to consider how long it takes for a person to die of hunger and how quickly he dies of thirst. You can live for weeks, even months, without food, but you die of thirst within a days. Accordingly, thirst is more nagging, harder to put up with, than hunger. [...] 'What did you children do in Auschwitz?' someone asked me recently.
} 
'Did you play games?' Games indeed! No, we had roll call instead. In Auschwitz I stood in rows of five and was thirsty and afraid of dying. That's it, that's all, that's the sum of it (2001:100).

In her attempt to analyse with a critical eye and with a certain detachment, as far as possible, as her trauma still breathes through every line of her volume of memoirs, Ruth Klüger acknowledges the predominance of male perspectives in the narration of Holocaust horrors, and once again, the minimalised role and importance of women's distinct voices in rendering traumatic experiences which eventually led to the trivialisation, to a certain extent, of their stories:

Occasionally, I tell a few stories of my own, if someone asks. But that rarely happens. Wars, and hence the memories of wars, are owned by the male of the species. [...] Besides, women have no past, or aren't supposed to have one. A man can have an interesting past, a woman only an indecent one (2001:18).

Ruth Klüger also devotes several pages to a topic that we have already mentioned, a topic which is recurrent throughout women's writings on the Holocaust, namely the emergence of camp-sister bonds between women, the Lagerschwestern. It was the feeling of belonging to a community, disregarding the atrocious circumstances in which these communities were formed, and the friendships flourishing in the midst of hell that prevented them from complete dehumanisation. Furthermore, the acts of heroism carried out by these women seem almost surreal given the circumstances, and the author narrates an episode which made a lasting impact on her:

I was saved by a young woman who was in as helpless a situation as the rest of us, and who nonetheless wanted nothing other than to help me. The more I think about the following scene, the more astonished I am about its essence, about someone making a free decision to save another person, in a place which promoted the instinct of self-preservation to the point of crime and beyond (2001:107).

Still Alive also contains harsh criticism of the legacy of the Holocaustof the museum culture which has grown up around the camps. Ruth Klüger deeply resents all easy comparisons and analogies, all naive and sentimental symbolisms associated with 
the Holocaust, as well as the fact that for some people, one of the greatest collective traumas of the twentieth century represents nothing but a manipulating tool which desecrates the memory of the victims:

The camps are part of a worldwide museum culture of the Shoah, nowhere more evident than in Germany, where every sensitive citizen, not to mention every politician who wants to display his ethical credentials, feels the need to take pictures at these shrines or, even better, have his picture taken (Kluger, 2001:63).

\subsection{Rendering Gender in Photography}

Photography is another essential artistic device which has shaped the representation of female gender in depictions of Nazi atrocities. As Barbie Zelizer (2001:251) has pointed out, there are four basic portrayals of women associated with the Holocaust:

- $\quad$ women portrayed as victims

- $\quad$ women portrayed as survivors

- $\quad$ women portrayed as perpetrators

- $\quad$ women portrayed as witnesses to what was transpiring in the camps

There are certain patterns and stereotypes that Holocaust-related photography has engendered in the case of women. For instance, female survivors are portrayed both individually and in group shots. Their faces usually show distress and agony, they have hollow cheekbones and vacant eyes. Female perpetrators, on the other hand, are always depicted as angry, harsh, often with maniacal eyes. In their case, there is an emphasis on the collective rather than on the individual. Female perpetrators seem to be the antithesis to all that has ever been expected and desired from women.

There were two main tendencies in documenting the Holocaust through photography:

gender was either wholly absent or wholly present. In the first case, women were depicted as genderless, namely their gender was neutralised, rendered invisible. In numerous instances, there was little or no visual marker of gender itself, as the piles of human bodies that appear in many photographs are indistinguishable. This suggests the 
universality of the Holocaust and of death, but it fails to particularise the different kinds of atrocities that different kinds of people had to bear. In the latter case, women were depicted as over-gendered, as the photos, mostly taken after the prisoners' liberation from the death camps and meant to show Nazi barbarism, emphasised women's vulnerability, their fragile bodies and vacant eyes. These over-gendered depictions ultimately upheld and reinforced stereotypes of women as domesticated beings, extremely fragile and vulnerable.

More or less the same effect is triggered by Holocaust museums and exhibits, as some researchers have pointed out that these displays fetishise the memory of the dead. Among the most recurrent and meaningful questions that are being asked are related to the extent to which these representations merely reinforce gender stereotypes, rather than accurately documenting the realities of women's lives in concentration camps. The accounts and the historical evidence that are privileged are those involving suffering and helplessness, while the memory of women's resistance in the face of Nazi terror is almost erased. However, as the history of the Holocaust shows and as was mentioned at the beginning of the present study, women assumed multiple roles, including overt or covert resistance, as well as taking extreme risks. Although such memories are not completely ignored, they are far less prevalent than those recollecting helplessness and submission.

\section{Conclusions}

To conclude, as Barbie Zelizer has pointed out,

the documentation of women's experience in the camps was thereby shaped to fit dominant cultural assumptions about women in culture and society. Perhaps because women were presumed to be more vulnerable than men, the brutality both against women and by women was seen as doubly atrocious, challenging gender-based expectations of women and broader expectations of humanity (2001:255).

While there were obviously common experiences among Holocaust victims that crossed gender boundaries, and the exploration of their representations would enable us to understand with more depth "the communal wound" (Reading, 2002:75-76) of the Holocaust, it is equally important to thoroughly research and analyse gender distinctions 
in the experiencing and inflicting of pain and trauma. The study of women during the Holocaust is essential not only in order to redress the absence of their lives and experiences in the documentation of Holocaust history, but also for the preservation of Holocaust memory. The predominance of one perspective upon these traumatic events leads to stereotypical representations, which only reinforce traditional gender roles, to misconceptions, numbness towards and eventually oblivion of everything that the Holocaust represents.

\section{References}

Bondy, R. 1998. "Women in Theresienstadt and the Family Camp in Birkenau" in D.

Ofer and L. J. Weitzman (eds.). Women and the Holocaust. New Haven, CT:

Yale University Press, pp.310-326.

Jacob, J. 2010. Memorializing the Holocaust. Gender, Genocide and Collective Memory. London: I.B. Tauris.

Langer, L. 1998. "Gendered Suffering? Women in Holocaust Testimonies" in D. Ofer and L. J. Weitzman (eds.). Women and the Holocaust. New Haven, CT: Yale University Press, pp.351-363.

Reading, A. 2002. The Social Inheritance of the Holocaust: Gender, Culture and Memory. New York: Palgrave Macmillan.

Ringelheim, J. 1998. "The Split between Gender and the Holocaust" in D. Ofer and L. J. Weitzman (eds.). Women and the Holocaust. New Haven, CT: Yale University Press, pp.349-350.

Rittner, C. and J. Roth (eds.). 1991. Women and the Holocaust: Different Voices. New York: Paragon.

Jewish Women. A Comprehensive Historical Encyclopedia [Online]. Available: http://jwa.org/encyclopedia/article/women-in-holocaust 